\title{
Bertrand Price Undercutting: \\ A Brief Classroom Demonstration
}

\author{
Andreas Ortmann
}

February 2002

Acknowledgement: I appreciate the constructive comments of Andrew Austin and three anonymous referees for the Journal of Economic Education. 


\section{Abstract}

I present a brief classroom demonstration illustrating Bertrand price undercutting. The classroom demonstration is appropriate for Micro Principles, and both intermediate and upper level undergraduate, as well as graduate classes in micro, Industrial Organization, and Game Theory.

\section{Abstrakt}

Článek popisuje jednoduchou demonstraci Bertrandovy cenové války (snižování cen v důsledku hospodářské soutěže), která může být provedena přímo ve třídě.

Demonstrace je vhodná pro výuku mikroekonomických principů na středně pokročilé až pokročilé vysokoškolské úrovni, a pro výuku mikroekonomie, průmyslové organizace a teorie her na úrovni doktorandského studia. 


\section{Introduction}

Bertrand price undercutting is arguably the key concept in analyzing the strategic interaction of price-setting oligopolists as well as in models of screening (e.g., Jehle \& Reny 2001). The classroom demonstration described below translates a lesson about price undercutting into a demonstration that takes as little as ten minutes and is likely to be remembered by students because of the significant amounts of money each of them could have won. So far, not one student has.

I first present design and implementation of the classroom demonstration (the "experiment"). Then I discuss the game theoretic solution of the presented experiment and my experiences with the present classroom demonstration and a closely related one. I conclude by discussing related literatures.

\section{The classroom demonstration: design \& implementation}

After a standard lecture on Cournot and Bertrand duopolists and oligopolists (e.g. drawing on Stiglitz 1997, Schotter 2000, or Binmore 1992), I introduce the experiment with the following instructions ${ }^{1}$ that I read aloud (and project on a screen):

${ }^{1}$ A referee of the original manuscript suggested that the instructions were too suggestive and proposed an alternative formulation which, slightly modified, I have since repeatedly used: "You are one of [the number of students in class] sellers who has to state a price between 0 and 100 Czech Koruns (nonnegative integers only) in order to sell a homogenous good to [the number of students in class] potential buyers. The seller with the lowest price will capture the entire market and will receive [difference of his price and marginal costs] x [number of students in class] Czech Koruns. If there are ties for the lowest price then the buyers are split among those who tie. Those with a higher price will receive nothing. Marginal costs are zero, and fixed costs are zero." This formulation, since it does not use the terms "Bertrand price undercutting" and "Bertrand competitor", should also be used if an instructor prefers to do the experiment before lecturing on Cournot and Bertrand competition. 
An experiment on Bertrand price undercutting:

Each of you is one of [the number of students in class] sellers in a market in which an unspecified homogenous good is traded. If you all charge a price of 100 Czech Koruns, buyers [the number of students in class] will distribute themselves evenly and each of you will earn 100 Czech Koruns. Of course, since each of you happens to be a Bertrand competitor, you are allowed to offer a lower price (nonnegative integers only). Marginal costs are zero, and fixed costs are zero.

Buyers are assumed to be price-conscious and will go for the slightest of differences. The Bertrand competitor with the lowest price will therefore capture all of the market and will get [the number of students in class] $x$ [difference between her or his price and the marginal cost]. Bertrand competitors with identical bids share the spoils (buyers).

\section{Questions?}

If there are no further questions, submit your price now. Please initial your record sheet, fold it, and submit it.

Let $\mathrm{n}$ be the number of students in the class, $\mathrm{T}$ be the number of students tied for the lowest submitted price, and $p_{\min }$ be the lowest price. Then the profit function of participant $i$ in this discrete version of the Bertrand price undercutting game is

$$
\begin{aligned}
& \Pi_{i}=p_{i} n \quad \text { if } \quad p_{i}<p_{j} \quad \forall i \neq j . \\
& \left(p_{i} n\right) / T \quad \text { if } p_{i}=p_{j}=p_{\text {min }} \text { for some } j \neq i \\
& 0 \quad \text { if } p i>p_{\min }
\end{aligned}
$$

For more than two players there are two obvious equilibria, requiring all to choose 1 or all to choose $0 .{ }^{2}$ The profit function invites the standard Bertrand price

2 There are also a number of not so obvious Nash equilibria if $\mathrm{p}_{\min }=0$ for $\mathrm{T}$ players such that $2<\mathrm{T}<\mathrm{n}$ while others set $\mathrm{p}>0$. Note that for $\mathrm{n}=2$, this discrete version of the Bertrand game introduces three Nash equilibria at $(0,0),(1,1)$, and $(2,2)$, all with zero or negligible profits. Of these equilibria, only $(1,1)$ is strict and hence may be viewed as "best". 
undercutting ("unraveling"). Prices of 0 and 100 are dominated by a price of 99 , which in turn is dominated by a price of 98 , etc. ${ }^{3}$

Multiple variations suggest themselves. For example, the stakes can be varied arbitrarily. ${ }^{4}$ Secondly, students are likely to argue that they would have done better had they been allowed to coordinate their strategy. The instructor therefore might want to afford them that very opportunity and allow students to appeal to the common interest either prior to a repeat round or before the first round. ${ }^{5}$ Thirdly, the instructor may want to introduce a marginal cost of 10 , thus setting the price range at $10-100$. This classroom demonstration is easy to implement. It requires only pieces of

Since the present classroom demonstration is not likely to be conducted in classes this small, I will not discuss the equilibrium selection problem in detail. See Dufwenberg et al. (2001) for such a discussion.

3 This unraveling is, of course, conditioned on the extreme price sensitivity induced by the postulated homogeneity of the good. The story for differentiated goods is different. See Binmore (1992), p. 335.

4 Stakes here means the money the instructor puts at stake. In the above instruction, for example, one could have used 50 Koruns or 200 Koruns instead, i.e., the price range can be contracted or expanded according to the instructor's risk attitude and budget constraint. It is likely that the attention of students is positively related to the amount of money that is at stake (Hertwig \& Ortmann 2001); it certainly is in my experience. For that reason alone I always use significant monetary payoffs in this classroom demonstration and related ones of the social dilemma variety. I never use credit points in classroom demonstrations: the payoff of a student being a function of others' action choices could mean that I am asking for trouble from a student who does not like her or his grade. That said, if an instructor is risk averse, has budget constraints, or is concerned about the use of monetary participant payments, credit points may be used in the obvious manner: just say points instead of Koruns and determine (beforehand) the conversion factor for credit points.

5 To make sure students write down their prices privately, the following addition to the instructions may be used in such a case: "You have ... minutes to discuss your optimal group strategy. (Hint: What happens if you all set a price of 100?) Do not write down your bid until you are asked to do so. Physical and other threats are unacceptable means of enforcement in this experiment." 
paper ("record sheets") on which students can write their prices. After the classroom experiment has been conducted I read aloud the submitted prices, pay off the winner(s), and then let the class discuss what happened. I often hear the suggestion during such discussions that everything would have ended differently had they been allowed to communicate beforehand.

\section{The classroom demonstration: experiences}

I conducted this experiment in a preparatory class of about 60 prospective graduate students at the Center for Economic Research and Graduate Education of Charles University in Prague in the summer of $2000 .^{6}$ At the time, 100 Czech Koruns corresponded to about 3 US dollars but was significantly more in terms of real purchasing power (especially for our students, who almost exclusively come from Central or East European transition countries): The sum total would have easily and generously financed the students' upcoming beer party. In any case, with 60 students it was clearly a high-stake gamble under any circumstance. Indeed, one student incredulously asked me whether I was serious about this classroom experiment. Not to worry: The lowest price (set by two people) was "1" and one other person set a price at "2", driving home the issue of Bertrand price undercutting, and the difficulty of collusion,

6 Students may object that such a large number of participants (Bertrand oligopolists) rarely exist in the real world. You may want to mention NASDAQ traders and bid-ask spreads before and after decimalization in response. You may also want to refer students to Selten (1973), whose theoretical work has since found convincing support in experimental research (e.g., Friedman 1996). 
powerfully. $^{7}$

I also used the experiment in the third course of our Micro core sequence. Of the 24 students attending class that day (the majority of whom had participated in the first experiment the previous summer), two offered a price of " 0 ", 13 offered a price of " 1 ", one each prices of "3", " 4 ", and "10", and six students offered "100". Two students submitted non-integer prices close to " 1 " and " 3 ". Most recently, I conducted this classroom experiment in a master's level Micro course at the University of Ljubljana, Slovenia. Bids of the 58 students attending the lecture were dispersed over the admissible range (nonnegative integers from 0 to 200), with a third clustering at 0 and 1 and less than 10 percent clustering between 195 and 200 tolars (roughly one dollar). ${ }^{8}$

These results are in line with the results reported in Ortmann \& Colander (1995) of the variant of collusion and common resource experiments (to be discussed briefly below), which is isomorphic to the present classroom demonstration.

In general, I have observed the following trends for these two classroom demonstrations: First, the higher the stakes, the more likely unraveling becomes. Second, allowing students to discuss the welfare maximizing solution will have a negligible effect on the outcome. (An instructor ought to make sure though that prices are written down privately, for otherwise peer pressure might be effective. Recall

7 I allowed students in this instance to discuss briefly what the optimal strategy would be for the class as a whole. I then let students write down their prices privately. About 85 percent of the students did write down a price of 100.

8 I both experiments described in this paragraph, I used the reformulation of the instructions proposed by an anonymous referee (see footnote 1.) However, I did not allow students to communicate. 
footnote 5.) Third, repetition of the experimental session leads to even stronger unraveling (if unraveling happened in the first round.)

\section{Related literature}

The classroom demonstration just presented is related to four literatures. First, there is the literature on classroom experiments on social dilemmas (Delemeester \& Brauer 2000). Specifically, the prisoner's dilemma has been used as a paradigm for price competition (e.g. Holt \& Capra 2000, p. 232). While it is useful to show students that a simple game like the prisoner's dilemma captures the essence of various strategic situations, idiosyncratic aspects of price undercutting such as the iterative nature of the unraveling process (= the iterated elimination of dominated strategies discussed above) are not captured. The current classroom experiment drives this point home effectively.

Second, this classroom experiment is related, and would be a natural introduction, to the rapidly increasing literature on guessing games and depths of reasoning, a topic which in my view is highly appropriate for intermediate and upperlevel, or even graduate, industrial organization and game theory and/or experimental classes. In the guessing game, participants are invited to submit a number between (and including) 0 and 100. (Several variants of this experiment exist, for example, nonnegative integers only or nonnegative rational numbers.) The winning number is the submission closest to the average of all submitted numbers multiplied by a number $p$.

If $p$ is taken from the open unit interval (e.g., 1/2), then it is trivial to see that the unique Nash equilibrium is 0 . One of the intriguing aspects of the guessing game is the 
opportunity that it allows to make inferences about the levels of depths of reasoning. Take for example the case of $p=1 / 2$. If everyone were to randomly draw their number from the interval $[0,100]$, then the average would likely be around 50 . The resultant number multiplied by $p \in(0,1)$ would have a good chance at being the winning number for a person who would anticipate correctly that everyone else will draw randomly (i.e., has "zero-order belief"). It is very likely, however, that most people engage in that kind of reasoning. Therefore that person who correctly anticipates other people's "first-order beliefs" (i.e., people's best response to what they believe is everyone else's zero-order belief) should best respond by multiplying 50 by $\mathrm{p}^{2}$. And so on. Note that the exponent of $p$ reflects the levels of iterative reasoning in which participants engage. Nagel (1995; see also her other articles) shows that participants typically employ one or two and, very occasionally, three such reasoning steps. This result has been shown to be robust across numerous subject pools.

Nagel (1995) spawned a most interesting literature on boundedly rational reasoning and the heterogeneity of agents. While this material strikes me as inappropriate for principles and intermediate classes, it should be introduced in upper level undergraduate and graduate courses. Since several nice summaries of the literature are available elsewhere (e.g., Nagel 1995, 1999; see also Nagel et al. 1999 ), the present brief summary shall suffice.

A third related piece of literature, Dufwenberg \& Gneezy (2000), explores the sensitivity of Bertrand price undercutting to the number of competitors. These authors find that the Bertrand solution does not predict well when the number of competitors is two, but predicts well (after participants have been given opportunities to learn) when 
the number of participants is three or four. ${ }^{9}$ This material addresses, among other issues, experimental design and implementation (e.g. Hertwig \& Ortmann 2001); it, too, however may be too advanced for principles and intermediate classes. That said, it makes for great material in upper level undergraduate and graduate game theory and/or experimental economics courses. Since Dufwenberg \& Gneezy (2000) is eminently readable, I will not elaborate here.

Finally, the problem presented here is isomorphic to the following variant of collusion and common resource experiments (experiment 5 in Ortmann \& Colander 1995):

I have here [number of students times number of quarters] dollars. You are to bid for these dollars privately by submitting to me a bid on a piece of paper. Whoever has the highest bid will get (...) dollars minus his or her bid. If several of you submit an identical bid, those students will share the difference between the (...) dollars and the value of their (identical) bids.

Note that a bidder in this scenario, like a price setter in the Bertrand priceundercutting game or a participant in the guessing game, has to figure out the most likely bid (price, number) of all other participants to determine the winning bid. Having gone through the requisite reasoning, a participant will understand that others might reason similarly, setting in motion the same unraveling process triggered in the Bertrand or guessing game scenarios.

9 Relatedly, I note that Dufwenberg, Gneezy, Goeree \& Nagel (2001) find evidence that for the case of 2 sellers and the price range $[10,100]$ the behavior unravels to the equilibrium, in contrast to the results reported in Dufwenberg \& Gneezy where the price floor was " 0 ". 


\section{Conclusion}

It is well-known that, although an increased emphasis on interactive teaching has materialized over the past five years, much of what happens in the economics classroom still fits the "chalk and talk" paradigm (Becker 2001). This unfortunate state of affairs has not been affected much by mounting evidence that classroom experiments can enhance the learning experience significantly (e.g., Gremmen \& Potters 1997). The present note offers a brief classroom demonstration that I found effective in my own teaching of Bertrand price undercutting. 


\section{REFERENCES}

Becker, W. E. 2001. Teaching methods in U.S. undergraduate economics courses. Journal of Economic Education 32 (3), 269 - 280.

Binmore, K. 1992. Fun and games. A text on game theory. Lexington, MA: DC Heath and Company.

Delemeester, G., and J. Brauer. 2000. Games economists play: Noncomputerized college classroom games, Journal of Economic Education, http://www.indiana.edu/ econed/archive.htm

Dufwenberg, M., and U. Gneezy. 2000. Price competition and market concentration: an experimental study. International Journal of Industrial Organization 18 (1), 7 - 22.

Dufwenberg, M., U. Gneezy, J. Goeree, and R. Nagel. 2001. Price floors and competition. Working paper. Available at http://www.econ.su.se/ md

Friedman, D. 1996. Equilibrium in evolutionary games: Some experimental results, Economic Journal 106 (1), 1 - 25.

Gremmen, H., and J. Potters. 1997. Assessing the efficacy of gaming in economic education. Journal of Economic Education 28 (4), 291 - 303.

Hertwig, R., and A. Ortmann. 2001. Experimental methods in economics: A challenge for psychologists? Behavioral and Brain Sciences 24 (3), 383 - 403.

Holt, C., and M. Capra. 2000. Classroom games: A prisoner's dilemma. Journal of Economic Education 31 (3), 229 - 36.

Jehle, G. A., and P. J. Reny. 2001. Advanced microeconomic theory. Second Edition. Boston: Addison Wesley.

Nagel, R. 1995. Unravelling in guessing games: An experimental study. American Economic Review 85 (5), 1313 - 26.

Nagel, R. 1999. A Keynesian beauty contest in the classroom. Expernomics (1999) 7 12. Available at http://www.marietta.edu/ delemeeg/expernom.html

Nagel, R. et al. 1999. One, two, (three), infinity: Newspaper and lab beauty-contest experiments. Working paper. Available at http://www.econ.upf.es/cgi-bin/onepaper?438

Ortmann, A., and D. Colander. 1995. Experiments in teaching and in understanding 
economics, Burr Ridge, IL: Irwin, 1995. Partially available at home.cerge.cuni.cz/ortmann/ (course materials links)

Schotter, A. 2000. Microeconomics. A modern approach. Reading, MA: Addison Wesley.

Selten, R. 1973. A simple model of imperfect competition where 4 are few and 6 are many. International Journal of Game Theory 2 (3), 141 - 201.

Stiglitz, J. 1997. Economics. Second Edition. New York: W.W. Norton. 